DOI: https://doi.org/10.24127/ajpm.v10i2.3671

\title{
ANALISIS KEBUTUHAN PENGEMBANGAN BAHAN AJAR ALJABAR LINEAR BAGI MAHASISWA PENDIDIKAN MATEMATIKA
}

\author{
Ira Vahlia ${ }^{1}$, Dwi Rahmawati ${ }^{2^{*}}$, Mustika $^{3}$, Tina Yunarti ${ }^{4}$, Nurhanurawati $^{5}$ \\ 1,2,3 Universitas Muhammadiyah Metro, Metro, Indonesia \\ ${ }^{4,5}$ Universitas Lampung, Bandar Lampung, Indonesia \\ * Jl. Kihajar Dewantara Iringmulyo Metro Timur, 34111, Metro, Indonesia. \\ E-mail: $\quad$ iravahlia562@gmail.com ${ }^{1)}$ \\ dwirahamawati1083@gmail.com $^{2 *)}$ \\ mustika@ummetro.ac.id ${ }^{3)}$ \\ tina.yunarti@yahoo.co.id ${ }^{4)}$ \\ nurha.nurawati@fkip.unila.ac.id ${ }^{5)}$
}

Received 07 April 2021; Received in revised form 09 June 2021; Accepted 30 June 2021

\begin{abstract}
Abstrak
Tujuan penelitian ini adalah untuk mengetahui bahan ajar aljabar linear yang perlu dikembangkan bagi mahasiswa pendidikan matematika. Penelitian ini merupakan penelitian deskriptif kualitatif. Subjek dalam penelitian ini adalah mahasiswa pendidikan matematika yang menempuh mata kuliah aljabar linear tahun akademik 2019/2020 di Universitas Muhammadiyah Metro. Sampel dalam penelitian ini diperoleh dengan teknik purposive sampling. Teknik pengumpulan data antara lain teknik observasi, wawancara, tes dan angket. Data yang telah diperoleh kemudian dianalisis. Data hasil observasi, wawancara dianalisis dengan tahapan mentranskrip data, menelaah data, mereduksi data, mendeskripsikan dan membuat kesimpulan. Untuk data hasil angket dan tes dianalisis dengan metode statistik deskriptif. Hasil penelitian menunjukkan bahwa bahan ajar pada perkuliahan aljabar linear masih menggunakan satu buah bahan ajar lama, mahasiswa membutuhkan bahan ajar yang mudah dipahami dan dapat digunakan secara mandiri, mahasiswa membutuhkan bahan ajar yang menuntun mahasiswa menemukan pengetahuan melalui pertanyaan-pertanyaan maupun langkah-langkah, serta mahasiswa membutuhkan bahan ajar yang mendukung dalam pembelajaran daring. Berdasarkan hasil penelitian diperoleh kesimpulan bahwa perlu dikembangkan bahan ajar Aljabar linear sesuai karakteristik mahasiswa dan perkembangan teknologi yang ada. Bahan ajar berupa e-modul berbasis Socrates merupakan salah satu alternatif bahan ajar aljabar linear yang diperlukan dalam memfasititasi pembelajaran daring. Selain itu, dengan modul berbasis Socrates yang berisi pertanyaan yang dapat menuntun mahasiswa dalam menemukan pengetahuan secara mandiri.
\end{abstract}

Kata kunci: Bahan ajar; e-modul; Socrates.

\section{Abstract}

The purpose of this research was to determine linear algebra teaching material that needs to be developed for mathematics education students. This research is a qualitative descriptive study. The subjects in this study were mathematics education students taking linear algebra courses for the 2019/2020 academic year at Universitas Muhammadiyah Metro. The sample in this study was obtained by the purposive sampling technique. The research data were collected by observation, interview, test and questionnaire. Data from observations and interviews were analyzed with the stages of transcribing data, analyzing dta, reducing data, describing and making conclusions. The questionnaire and test data were analyzed using descriptive statistical methods. The result shows that the teaching materials in linear algebra lectures still used one old teaching material, Students needed teaching materials that were easy to understand and could be used independently, students needed teaching materials that led students to find knowledge through questions or steps, and students need teaching materials that support online learning. Based on the research results, it was concluded that it is necessary to develop linear algebra teaching materials according to the characteristics of students and existing technological developments. The teaching material in the form of a Socrates-based e-module is an alternative to the linear algebra teaching material needed to facilitate online learning. Also, with a Socrates-based module that contains questions that can guide students in finding knowledge independently.

Keywords: E-module; Socrates; teaching material.

This is an open access article under the Creative Commons Attribution 4.0 International License 
DOI: https://doi.org/10.24127/ajpm.v10i2.3671

\section{PENDAHULUAN}

Pada era digital saat ini, baik dosen maupun mahasiswa harus mampu mengikuti perkembangan teknologi. Mahasiswa secara mandiri mengakses berbagai referensi ataupun sumber yang berhubungan dengan materi. Untuk dapat menguasai kompetensi yang dibutuhkan dalam dunia kerja, mahasiswa harus memiliki kemampuan yang terdiri atas aspek pengetahuan, sikap dan keterampilan umum dan khusus. Mahasiswa yang dapat terus berkembang, yaitu yang mempunyai kemampuan berpikir kritis, kreatif, produktif, mandiri, dan bekerjasama dengan baik. Kemajuan teknologi yang ada dapat diamati pada mahasiswa Universitas Muhammadiyah Metro kebanyakan memiliki handphone android dan laptop yang digunakan dalam pembelajaran untuk mencari sumber referensi melalui internet.

Aljabar linear merupakan matakuliah wajib mahasiswa program studi pendidikan matematika yang ditempuh pada semester 4 di Universitas Muhammadiyah Metro. Matakuliah ini berbobot 2 sks dengan capaian pembelajaran adalah mahasiswa dapat memahami konsep tentang vektor di $R^{2}$ dan $R^{3}$, ruang vektor Euclidean, ruang vektor umum, ruang hasil kali dalam, nilai eigen-vektor eigen dan transformasi linear.

Beberapa penelitian yang berkaitan dengan aljabar linier telah banyak dilakukan, seperti penelitian tentang penyelesaian soal aljabar linier menggunakan pendekatan joint action studies (Hariyani \& Murniasih, 2019); peningkatan level berpikir aljabar (Jamil, 2017); pengembangan modul pembelajaran aljabar linier dan matriks dengan pendekatan inkuiri (Aminah \& Radita, 2020); pengembangan materi aljabar linier dengan model Problem
Based Learning (PBL) (Sinaga \& Sijabat, 2020). Dari beberapa penelitian yang telah ada akan dijadikan dasar untuk pengembangan bahan ajar aljabar linear bagi mahasiswa pendidikan matematika universitas muhammadiyah metro.

Berdasarkan hasil analisis tes menunjukkan bahwa mahasiswa merasa kesulitan saat menyelesaikan permasalahan yang diberikan, seperti menginterpretasi masalah, analisis, evaluasi dan menarik kesimpulan. Mahasiswa masih sangat bergantung pada dosen saat menyelesaikan soalsoal yang ada. Indikator ini menunjukkan bahwa kemampuan berpikir kritis mahasiswa masih terbatas. Menurut hasil penelitian (Firdaus et al., 2015) diketahui bahwa berpikir kritis adalah salah satu indikator penting bagi mahasiswa untuk berkompetisi di dunia kerja dan kehidupan pribadi, mahasiswa harus memiliki kemampuan untuk menyelesaikan masalah dan harus mampu berpikir kritis. Hal ini menunjukkan bahwa penting bagi mahasiswa untuk memiliki kemampuan berpikir kritis. Salah satu faktor yang mempengaruhi kemampuan berpikir kritis adalah penggunaan bahan ajar yang tepat dalam proses pembelajaran. Hal ini sejalan dalam penelitian (Sari \& Anantyarta, 2018), bahwa faktor-faktor yang mempengaruhi kemampuan mahasiswa antara lain model atau metode pembelajaran, media pembelajaran, bahan ajar, sarana dan prasarana.

Lebih lanjut, hasil observasi menunjukkan bahwa bahan ajar yang digunakan dalam pembelajaran matakuliah aljabar linear pada saat ini masih sangat terbatas jenisnya yaitu berupa sebuah buku teks. Dan mahasiswa masih kesulitan dalam memahami materi dalam bahan ajar 
tersebut. Mahasiswa butuh pendampingan setiap menggunakan bahan ajar tersebut, dengan kata lain bahan ajar yang ada belum bisa memfasilitasi mahasiswa belajar mandiri. Hasil penelitian (Dimas et al., 2017) mengatakan bahwa mahasiswa mengalami kesulitan dalam menggunakan bahan ajar berupa buku, sehingga diperlukam bahan ajar modul. Untuk itu perlu adanya bahan ajar yang dapat digunakan mahasiswa secara mandiri untuk mengonstruksi konsep salah satunya modul. Sejalan dengan perkembangan teknologi saat ini dan pelaksanaan pembelajaran secara daring, maka perlu ada bahan ajar yang dapat diakses mahasiswa secara daring sehingga memudahkan penggunaannya dalam pembelajaran saat ini.

Berdasarkan uraian di atas, tujuan penelitian ini untuk mengetahui bahan ajar aljabar linear yang perlu dikembangkan bagi mahasiswa pendidikan matematika. Hasil dari penelitian ini diharapkan dapat memberikan informasi terkait bahan ajar yang akan dan perlu dikembangkan pada penelitian selanjutnya.

\section{METODE PENELITIAN}

Penelitian ini merupakan penelitian deskriptif kualitatif. Subjek dalam penelitian ini adalah mahasiswa semester 4 pendidikan matematika FKIP Universitas Muhammadiyah Metro yang menempuh mata kuliah aljabar linear. Sampel dalam penelitian ini diperoleh dengan teknik purposive sampling. Objek kajian dalam penelitian ini mencakup: 1) kesesuaian bahan ajar dengan materi, 2) bahan ajar yang digunakan oleh dosen, 3) kebutuhan mahasiswa terkait bahan ajar, dan 4) kesulitan mahasiswa dalam mempelajari materi aljabar linear. Tahapan penelitian terdiri dari tahapan prasurvei, pengumpulan data, pengolahan data dan pelaporan. Data penelitian dikumpulkan dengan teknik observasi, wawancara, tes dan penyebaran angket. Lembar observasi dan wawancara digunakan untuk memperoleh data penggunaan bahan ajar dalam pembelajaran aljabar linear. Sedangkan instrumen angket dan tes diberikan kepada mahasiswa. Angket digunakan untuk mengetahui pandangan tentang kebutuhan bahan ajar matematika, tes digunakan untuk mengetahui kemampuan berpikir kritis mahasiswa.

Teknik analisis data dilakukan dengan tahapan mentranskrip data, menelaah data, mereduksi data, mendeskripsikan, dan membuat kesimpulan untuk data wawancara dan observasi. Sedangkan data angket dan tes dianalisis secara kuantitatif dengan dijelaskan secara deskriptif.

\section{HASIL DAN PEMBAHASAN}

Kemampuan berpikir kritis merupakan salah satu soft skill yang harus dimiliki mahasiswa guna menghadapi perkembangan dunia yang sangat cepat saat ini. Persaingan dunia kerja semakin kompetitif serta makin berkembangnya ilmu pengetahuan dan teknologi informasi. Perguruan tinggi sebagai pelaksana pendidikan mempunyai peran dalam menyiapakan mahasiswa untuk dapat bersaing dimasa depan yang serba digital. Salah satu upaya yang dapat dilakukan yaitu meningkatkan kualitas pembelajaran untuk mengembangkan kemampuan berpikir kritis mahasiswa. Hal terkait pembelajaran harus mendukung dalam mengembangkan kemampuan berpikir kritis, salah satunya adalah penggunaan bahan ajar.

Berdasarkan tujuan penelitian dan perlunya mengembangkan kemampuan berpikir kritis mahasiswa, maka perlu 
DOI: https://doi.org/10.24127/ajpm.v10i2.3671

dilakukan analisis terlebih dahulu terkait kemampuan berpikir kritis mahasiswa. Data yang digunakan dalam analisis berpikir kritis mahasiswa diperoleh dari hasil UTS yang berbentuk soal essay yaitu soal satu sampai dengan tiga, didalamnya mengukur interpretasi masalah, analisis, evaluasi dan menarik kesimpulan. Adapun hasil analisis kemampuan berpikir kritis dapat dilihat pada Tabel 1.

Tabel 1. Analisis kemampuan berpikir kritis

\begin{tabular}{lcccccc}
\hline \multirow{2}{*}{$\begin{array}{c}\text { Kemampuan Berpikir } \\
\text { Kritis }\end{array}$} & \multicolumn{2}{c}{ Soal essay 1 } & \multicolumn{2}{c}{ Soal essay 2 } & \multicolumn{2}{c}{ Soal essay 3 } \\
\cline { 2 - 7 } & Benar & Salah & Benar & Salah & Benar & Salah \\
\hline Menginterpretasi masalah & $19,85 \%$ & $80,15 \%$ & $15,01 \%$ & $84,99 \%$ & $9,55 \%$ & $90,45 \%$ \\
Analisis & $30,58 \%$ & $69,42 \%$ & $24,39 \%$ & $75,61 \%$ & $27,68 \%$ & $72,32 \%$ \\
Evaluasi & $12,66 \%$ & $87,34 \%$ & $37,21 \%$ & $62,79 \%$ & $14,63 \%$ & $85,37 \%$ \\
Menarik kesimpulan & $13,04 \%$ & $86,96 \%$ & $37,66 \%$ & $62,34 \%$ & $11,22 \%$ & $88,78 \%$ \\
\hline Rata-rata & $\mathbf{1 9 , 0 3 \%}$ & $\mathbf{8 0 , 9 7 \%}$ & $\mathbf{2 8 , 5 7 \%}$ & $\mathbf{7 1 , 4 3 \%}$ & $\mathbf{1 5 , 7 7 \%}$ & $\mathbf{8 4 , 2 3 \%}$ \\
\hline
\end{tabular}

Dari Tabel 1, diperoleh data bahwa mahasiswa yang menjawab dengan benar aspek berpikir kritis $19,03 \%$ pada soal essay $1,28,57 \%$ soal essay 2 dan $15,77 \%$ soal essay 3, sehingga diperoleh rata-rata sebesar $21,12 \%$. Ini menunjukkan bahwa kemampuan berpikir kritis mahasiswa matematika memiliki kategori sangat kurang. Hal ini terjadi pada keempat indikator berpikir kritis. Pada indikator menginterpretasi masalah soal, rata-rata mahasiswa menjawab benar $14,80 \%$ atau dalam kategori sangat kurang. Untuk indikator analisis, rata-rata mahasiswa menjawab benar sebesar $27,55 \%$ atau dalam kategori sangat kurang. Sedangkan untuk aspek evaluasi dan menarik kesimpulan masing-masing sebesar $20,51 \%$ dan $20,64 \%$ yang termasuk kategori sangat kurang. Ini menunujuk-kan bahwa masih ada mahasiswa yang belum mampu menginterpretasi masalah, menganalisis, mengevaluasi dan enarik kesimpulan dengan benar

Berdasarkan hasil wawancara dengan beberapa mahasiswa, tentang bahan ajar yang digunakan oleh dosen yaitu buku teks, diperoleh informasi bahwa mahasiswa masih kesulitan dalam memahami bahasa dan uraian pembahasan yang disajikan. Hal ini dikarenakan buku teks yang digunakan merupakan buku terjemahan, sehingga mahasiswa perlu pendampingan penuh dalam menggunakan bahan ajar tersebut. Selain itu, bahan ajar tersebut belum dapat memfasilitasi pembelajaran daring secara maksimal. Untuk itu, perlu adanya bahan ajar tambahan yang mendukung pembelajaran mahasiswa secara mandiri dan mengikuti perkembangan teknologi yang ada.

Menurut (Changwong et al., 2018) bahwa kemampuan berpikir kritis pada mahasiswa merupakan salah satu pilar utama baru berbasis pengetahuan yang sangat penting untuk ditingkatkan dalam pembelajaran. Salah satu caranya penggunaan bahan ajar yang sesuai kebutuhan mahasiwa. Bahan ajar yang mampu memfasilitasi mahasiswa mengembangkan kemapuan berpikir kritis perlu dikembangkan. Melalui bahan ajar tersebut mahasiswa terbiasa secara mandiri belajar untuk memecahkan masalah dengan menganalisis argumen yang dimiliki untuk mendapat kesimpulan. Bahan ajar yang demikian adalah berupa modul. Modul merupakan bahan ajar yang dapat membantu mahasiswa belajar secara mandiri. Mahasiswa dapat membangun 
sendiri pengetahuan secara aktif dalam proses pembelajaran dengan menggunakan modul (Anwar \& Rahmawati, 2017).

Metode Socrates adalah proses pertanyaan yang menuntun mahasiswa dalam mengonstruksi pengetahuan dengan langkah-langkah secara terurut (Yunarti, 2016). Dengan menerapkan metode socrates dalam pembelajaran, mahasiswa dapat berpikir kritis serta dapat memikirkan langkah-langkah sederhana terlebih dahulu dalam menyelesaikan permasalahan, serta dapat membiasakan mahasiswa untuk memperoleh pengetahuan tanpa diberi tahu terlebih dahulu oleh dosen. Susunan pertanyaan Socrates yang diajukan dosen kepada mahasiswa pun mengikuti kaidah metode ilmiah. Oleh karena itu, metode Socrates dapat digolongkan sebagai salah satu metode yang berbasis pendekatan saintifik. Hasil penelitian (Ernawati \& A Muhajir Nasir, 2018) disimpulkan bahwa penerapan metode socrates dapat meningkatkan hasil belajar matematika pada mahasiswa prodi pendidikan matematika. Berdasarkan informasi di atas menunjukkan bahwa bahan ajar berbasis Socrates dapat dijadikan alternative dalam meningkatkan kemampuan berpikir kritis mahasiswa.

Data hasil angket yang telah diisi 34 mahasiswa semester 4 Pendidikan Matematika dapat dilihat pada Tabel 2.

Tabel 2. Hasil respon angket mahasiswa

\begin{tabular}{ccc}
\hline No & Ya & Tidak \\
\hline 1 & $82,35 \%$ & $17,65 \%$ \\
2 & $88,24 \%$ & $11,76 \%$ \\
3 & $85,29 \%$ & $14,71 \%$ \\
4 & $26,47 \%$ & $73,53 \%$ \\
5 & - & $100 \%$ \\
6 & - & $100 \%$ \\
7 & - & $100 \%$ \\
8 & - & $100 \%$ \\
9 & $79,41 \%$ & $20,59 \%$
\end{tabular}

\begin{tabular}{ccc}
\hline No & Ya & Tidak \\
\hline 10 & - & $97,06 \%$ \\
11 & - & $76,47 \%$ \\
12 & $94,12 \%$ & $5,88 \%$ \\
13 & $100 \%$ & - \\
14 & $94,12 \%$ & $5,88 \%$ \\
15 & $100 \%$ & - \\
\hline
\end{tabular}

Respon mahasiswa terhadap kebutuhan bahan ajar aljabar linear, angket no 1 menunjukkan bahwa $82,35 \%$ mahasiswa telah memiliki buku teks aljabar linear. Ini berarti mayoritas mahasiswa sudah memiliki bahan ajar berupa buku teks. Namun, berdasarkan respon mahasiswa terhadap angket no 3 menunjukkan bahwa 85,29\% mahasiswa mengalami kesulitan dalam memahami materi dalam buku teks yang digunakan. Mahasiswa mengalami kesulitan dalam mengerjakan soal-soal aljabar linear karena belum terdapat bahan ajar yang dapat secara mandiri dipelajari oleh mahasiswa serta format yang kurang jelas, ada beberapa sub pokok yang memang materinya sangat sulit dicari oleh mahasiswa, walaupun sudah mencari ke beberapa referensi seperti dari internet ataupun buku yang ada. Mahasiswa memiliki buku teks hanya satu saja namun mahasiswa masih kesulitan dalam memahami tanpa dituntun dosen, mahasiswa tidak memiliki buku referensi lain sebagai alternatif yang dapat digunakan untuk mempelajari materi aljabar linear dapat dilihat pada soal angket nomor 12, mahasiswa sudah berusaha mencari sumber lain, tetapi mahasiswa belum menemukan yang mudah dipahami.

Menurut respon mahasiswa, dalam pembelajaran belum ada aplikasi bahan ajar yang memudahkan pembelajaran di dalam kelas yang dapat dilihat pada respon mahasiswa menjawab tidak sebanyak $100 \%$ pada soal angket nomor 5-8. Berdasarkan soal angket nomor 15 semua mahasiswa 
setuju sebanyak $100 \%$ jika ada bahan ajar e-modul berbantu aplikasi android yang digunakan dalam pembelajaran aljabar linear. Selanjutnya berdasarkan wawancara terhadap mahasiswa sebagai lanjutan dari hasil respon mahasiswa diperole hasil bahwa mahasiswa membutuhkan bahan ajar yang memuat langkah-langkah terurut sebagai panduan untuk mengonstruksi pengetahuan secara mandiri. Berdasarkan hasil respon mahasiswa tersebut menunjukkan bahwa mahasiswa membutuhkan bahan ajar yang didalamnya memuat pertanyaan-pertanyaan yang mampu menuntun mahasiswa dalam membangun pengetahuan terkait aljabar linear secara mandiri. Selain itu, mahasiswa juga mengharapkan bahan ajar berbantu aplikasi android yang dapat dengan mudah digunakan dalam pembelajaran.

Berdasarkan Peraturan Rektor UM Metro No. 686/11.3.AU/ F/ Per/ UMM/ 2019 Pasal 9 ayat 4 yang menyatakan bahwa bahan ajar wajib diperbaiki mengikuti perkembangan teknologi. Perkembangan teknologi khususnya dalam program aplikasi saat ini memberikan kemudahan dalam pendidikan. Untuk itu, perlu dikombinasikan e-modul berbasis Socrates dengan teknologi yang berkembang. E-modul merupakan bentuk modul secara digital dan berisi materi dalam bentuk video dan animasi yang mampu membuat mahasiswa belajar lebih interaktif. sehingga capaian pembelajaran yang direncanakan dapat dicapai.

Menurut (Tania, 2017) proses pengembangan IT salah satunya yaitu dengan mengembangkan bahan ajar modul cetak menjadi modul elektronik atau e-Modul. Mahasiswa merasa senang mempelajari e-modul dibandingkan bahan ajar cetak karena didalamnya adanya fasilitas multimedia seperti gambar, animasi, video dan audio. Dengan adanya e-modul, mahasiswa dapat mengerjakan soal secara interaktif karena mahasiswa dapat melakukan evaluasi diri sendiri kapanpun dan dimanapun berapa terhadap suatu kompetensi serta berfungsi sebagai multiplatform yaitu dapat digunakan pada berbagai peralatan seperti laptop dan handphone. Salah satu aplikasi android yang dikembangkan yaitu android mobile aplication. Dari hasil (Holla \& Katti, 2012) dapat terlihat bahwa di dunia teknologi yang berkembang pesat, android Mobile aplikasi adalah aplikasi yang berkembang pesat dari ponsel global pasar.

Aplikasi seluler berkembang dengan kecepatan meteor untuk memberi penggunanya pengalaman pengguna yang mudah dan cepat. Menurut (Perdana et al., 2017) untuk merancang dan mengembangkan modul elektronik dapat mengkolaborasikan keterampilan proses sehingga dapat diperoleh peningkatan keterampilan berpikir kritis. Berdasarkan hasil penelitian (Vahlia, 2017), agar mahasiswa dapat belajar secara mandiri dan beradaptasi dengan teknologi, $e$ learning diperlukan berdasarkan bahan ajar dimana dosen tidak harus membimbing siswa satu per satu, tetapi para mahasiswa juga dapat saling membantu dengan bantuan internet. Dari beberapa hasil penelitian tersebut, mengembangkan E-modul berbantu aplikasi android sangat penting dalam pembelajaran yang berlangsung tiga arah yaitu mahasiswa dengan sumber belajar, dosen mahasiswa dan sesama mahasiswa sendiri secara mandiri sehingga mempermudah dalam berinteraksi secara mandiri. E-modul berbantu aplikasi android merupakan 
modul yang dikolaborasikan dengan system android berupa aplikasi yang mudah diakses mahasiswa dalam smartphone android.

Hasil penelitian (Herawati \& Muhtadi, 2018), e-modul atau elektronik modul adalah modul dalam bentuk digital elektronik yang didalamnya terdapat teks, gambar maupun keduanya berisi materi disertai dengan simulasi sehingga dapat digunakan untuk mencapai tujuan pembelajaran. Sedangkan (Suarsana \& Mahayukti, 2013) menyatakan bahwa penggunaan e-modul berorientasi pemecahan masalah, keterampilan berpikir kritis mahasiswa mengalami peningkatan. Hal ini sejalan dengan hasil penelitian ini, bahwa mahasiswa membutuhkan bahan ajar berupa emodul untuk meningkatkan kemampuan berpikir kritis

\section{KESIMPULAN DAN SARAN}

Berdasarkan hasil dan pembahasan di atas, dapat disimpulkan bahwa perlu dikembangkan bahan ajar aljabar linear bagi mahasiswa pendidikan matematika. Salah satu alternatif bahan ajar yang dapat dikembangan berupa emodul berbasis socrates berbantu aplikasi android.

Saran dalam penelitian ini perlu dilakukan penelitian lanjutan terkait pengembangan e-modul aljabar linear berbasis Socrates berbantu aplikasi android untuk meningkatkan ketrampilan berpikir kritis dan hasil belajar mahasiswa dan melihat efektifitas dari e-modul tersebut.

\section{DAFTAR PUSTAKA}

Aminah, S., \& Radita, N. (2020). Pengembangan modul pembelajaran aljabar linier dan Matriks dengan pendekatan inkuiri untuk mahasiswa Teknik informatika. MUST: Journal of Mathematics Education, Science and Technology, 5(2), 156-170.

Anwar, R. B., \& Rahmawati, D. (2017). The use of mathematical module based on constructivism approach as media to implant the concept of algebra operation. International Electronic Journal of Mathematics Education, 12(3), 579-583.

Changwong, K., Sukkamart, A., \& Sisan, B. (2018). Critical thinking skill development: Analysis of a new learning management model for Thai high schools. Journal of International Studies, 11(2), 1112.

Dimas, A., Cari, C., Suparmi, A., Sarwanto, S., \& Handhika, J. (2017). Profil Analisis Kebutuhan Bahan Ajar Mahasiswa Materi Dinamika Gerak pada Mata Kuliah Fisika Dasar. Prosiding SNFA (Seminar Nasional Fisika Dan Aplikasinya), 1, 42-45.

Ernawati, \& A Muhajir Nasir. (2018). Efektivitas Metode Pembelajaran Socrates Kontekstual Berbasis Gaya Kognitif terhadap Hasil Belajar Statistik Dasar. Proximal: Jurnal Penelitian Matematika Dan Pendidikan Matematika, 1(2), 3144.

Firdaus, F., Kailani, I., Bakar, M. N. Bin, \& Bakry, B. (2015). Developing Critical Thinking Skills of Students in Mathematics Learning. Journal of Education and Learning (EduLearn), 9(3), 226-236. https://doi.org/10.11591/ edulearn.v9i3.1830

Hariyani, S., \& Murniasih, T. R. (2019). Penyelesaian Soal Aljabar Linier Menggunakan Pendekatan Joint Action Studies. AKSIOMA: Jurnal Program Studi Pendidikan Matematika, 8(3), 542-550. 
Herawati, N. S., \& Muhtadi, A. (2018). Pengembangan modul elektronik (e-modul) interaktif pada mata pelajaran Kimia kelas XI SMA. Jurnal Inovasi Teknologi Pendidikan, 5(2), 180-191.

Holla, S., \& Katti, M. M. (2012). Android based mobile application development and its security. International Journal of Computer Trends and Technology, 3(3), 486490.

Jamil, A. F. (2017). Peningkatan Level Berpikir Aljabar Siswa Berdasarkan Taksonomi SOLO Pada Materi Persamaan Linier Melalui Pemberian Scaffolding. JIME, 3(1), 175-183.

Perdana, F. A., Sarwanto, S., Sukarmin, S., \& Sujadi, I. (2017). Development of e-module combining science process skills and dynamics motion material to increasing critical thinking skills and improve student learning motivation senior high school. International Journal of Science and Applied Science: Conference Series, 1(1), 45-54.

Sari, N. K., \& Anantyarta, P. (2018). Pengembangan Petunjuk Praktikum Histologi Program Studi Pendidikan Biologi. BIOMA: Jurnal Biologi Dan Pembelajaran Biologi, 3(2).

Sinaga, C. V. R., \& Sijabat, A. (2020). Pengembangan Materi Aljabar Linier dengan Model Problem Based Learning dalam Upaya Meningkatkan Kemampuan Komunikasi Matematis Siswa SMP. MAJU: Jurnal Ilmiah Pendidikan Matematika, 7(2), 171177
Suarsana, I. M., \& Mahayukti, G. A. (2013). Pengembangan E-Modul Berorientasi Pemecahan Masalah Untuk Meningkatkan Keterampilan Berpikir Kritis Mahasiswa. Jurnal Nasional Pendidikan Teknik Informatika (JANAPATI), 2(3), 193.

https://doi.org/10.23887/janapati.v 2i3.9800

Tania, L. (2017). pengembangan bahan ajar e-modul sebagai pendukung pembelajaran kurikulum 2013 pada materi ayat jurnal penyesuaian perusahaan jasa siswa kelas $\mathrm{x}$ akuntansi smk negeri 1 surabaya. Jurnal Pendidikan Akuntansi (JPAK), 5(2).

Vahlia, I. dan R. E. (2017). Pengembangan Bahan Ajar Berbasis E Learning Pada Matakuliah Evaluasi Pembelajaran Untuk Meningkatkan Hasil Belajar Mahasiswa. AKSIOMA: Jurnal Program Studi Pendidikan Matematika, 6(2), 169. https://doi.org/10.24127/ajpm.v6i2. 1038

Yunarti, T. (2016). Metode Socrates Dalam Pembelajaran Berpikir Kritis. Graha Ilmu. 